肝内 HBV DNA に及ぼすインターフェロン療法の効果と 血中 $\mathrm{B}$ 型肝炎ウイルスマーカーの推移

一治療後の肝炎の再燃との関連を中心に一

$\begin{array}{cccccc}\text { 松本 } & \text { 昌之 }^{* 1)} & \text { 奥野 } & \text { 忠雄*2) } & \text { 武田 } & \text { 誠 } \\ \text { 進藤 } & \text { 道子 } & \text { 新井 } & \text { 賢 } & \text { 瀧野 } & \text { 辰郎*1) } \\ \text { 山田 } & \text { 明 } & \text { 今西 } & \text { 二郎*3) } & \text { 宗川 } & \text { 吉注*4) }\end{array}$

はじめに：B 型慢性肝炎に対するインターフェロン （IFN）療法後の肝炎の鎮静化には HBe 抗原の消失が 重要な役割を演している.しかし IFN 投与により一旦 $\mathrm{HBe}$ 抗原が消失した例でもその後の経過中に肝资の 再燃をみる例がある. 我々はIFN 投与前後の肝内 B 型肝炎ウイルス (HBV) DNA を分析し, IFN 治療が 肝内 HBV DNA の増殖形態に及ぼす効果と血中 $\mathrm{HBV}$ マーカーの推移との関係から, 主として肝资の 再燃との関連を中心に検討した。

対象と方法：IFN 治療を施行した HBe 抗原陽性の B 型慢性肝炎12例を対象とした. HuIFN- $\alpha$ ないしは $\beta$ を一日 300 - 600万 IU を 4 邁連続投与し，投与直前 之終了 1 週後に得た肝生検組織から, 肝組織 DNAを 抽出し，その $10 \mu \mathrm{g}$ を用いて Southern blot hybridization.法にて肝内 $\mathrm{HBV}$ DNA を検索した。 血中 $\mathrm{HBV}$ DNA は ${ }^{32} \mathrm{P}$ 標識 HBV DNA probeを用いた dot hybridization 法にて測定した. Pre-S2抗原はEIA 法 (特殊免疫研究所キット)で測定し，492nm の OD 值を Pre-S2抗原価とした（陰性 $<0.50 D ）$.

結果：肝内 HBV DNA は IFN 投与前 2 例を除 全例で single-stranded(SS), supercoiled(SC), linear and full-length circular (L), partially doublestranded(PDS) HBV DNA の各堌殖形態がみられた。 組み込み HBV DNA は1例もみられなかった，IFN 治療後肝内 HBV DNA 2 例で消失し 8 例で DNA 量が減少した。减少した 8 例のうち 2 例では SCのみ が残存したが他の 6 例ではSS, SC, L, PDS の全增殖

\footnotetext{
*1) 京都府立医大第 3 内科

*2) 明石市立市民病院内科

*3) 京都府立医大钽生物学

*4) 京都工芸纎維大学

<受付日63年 8 月 15 日 $>$
}

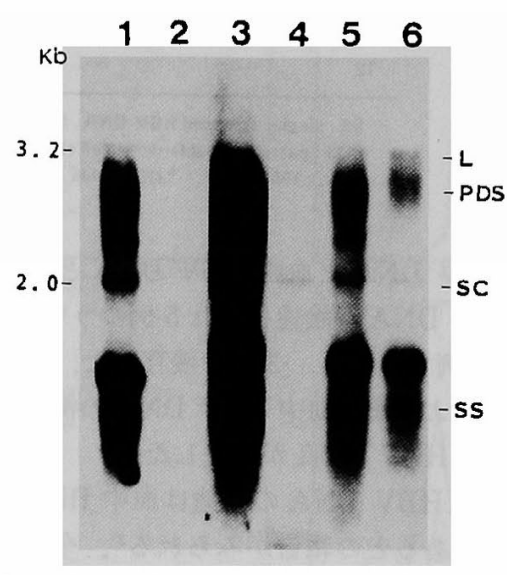

Fig. Autoradiogram of hepatic HBV DNA Lane $1 \& 2$ : case 1 before and after IFN Lane $3 \& 4$ : case 3 before and after IFN Lane $5 \& 6$ : case 5 before and after IFN

形態がみられた．投与前陰性の 2 例は投与後も陰性で あった (Fig.). 血中 HBV DNA は投与前 2 例を除き 陽性で投与後に 5 例が陰性化した. Pre-S2抗原は投与 前全例が陽性で投与後 3 例が陰性化した. $\mathrm{HBe}$ 抗原は 投与後 4 例が陰性化した (Table). 治療後 1 年以上経 過観察しえた 6 例のうち投与後肝内 HBV DNA が陰 性であった 2 例（cases 1 and 11）とSCのみ残存した 1 例 (case 3) では投与後に alanine aminotransferase (ALT) が正常化した. しかし case 1 と case 11はその 後血中 HBV DNA の再上昇とともに ALT が再上昇 した. Pre-S2抗原は IFN 投与後 case 1と11で持続陽 性, case 3は陰性化した。

考察：肝内 HBV DNA はIFN 投与により全例で 減少ないしは消失した。各増殖形態の中では既報”の ごとくSCが消失しにくい傾向がみられた. 
Table Changes of hepatic and serum HBV DNA, Pre-S $\mathrm{Ag}$ and $\mathrm{HBe} \mathrm{Ag}$ in patients with chronic hepatitis, type $\mathrm{B}$ before and after IFN

\begin{tabular}{|c|c|c|c|c|c|c|c|c|c|}
\hline \multirow{2}{*}{ case } & \multicolumn{2}{|c|}{ hepatic HBV DNA } & \multicolumn{2}{|c|}{ serum HBV DNA* } & \multicolumn{2}{|c|}{ Pre-S, Ag ${ }^{h}$} & \multicolumn{2}{|c|}{$\mathrm{HBe} \mathrm{Ag}$} & \multirow{2}{*}{$\frac{\text { ALT level }}{\text { c }}$} \\
\hline & before & after & before & after & before & after & before & after & \\
\hline 1 & SS, SC, L, PDS & - & +4 & 0 & 1.72 & 9.94 & + & - & abnormal \\
\hline 2 & SS. SC. L, PDS & - & +1 & 0 & 1.06 & 0.22 & + & - & \\
\hline 3 & SS, SC, L. PDS & sc & +3 & 0 & 0.58 & 0.46 & + & - & normal \\
\hline 4 & N. D & sc & +2 & +1 & 0.79 & 0.41 & + & + & \\
\hline 5 & SS. SC. L, PDS & SS, SC, L, PDS & +3 & +3 & 1.58 & 0.78 & + & + & abnormal \\
\hline 6 & SS, SC, L, PDS & SS, SC, L, PDS & +3 & +3 & 1.05 & 1.78 & + & + & abnormal \\
\hline 7 & SS, SC, L, PDS & SS, SC, L, PDS & +3 & +1 & 1.90 & 1.88 & + & + & abnormal \\
\hline 8 & SS, SC, L, PDS & SS, SC, L, PDS & +2 & 0 & 1.72 & 1.73 & + & + & \\
\hline 9 & SS, SC. L, PDS & SS, SC, L, PDS & +4 & +3 & 1.71 & 1.70 & + & + & \\
\hline 10 & SS, SC, L, PDS & ss, sc, L, PDS & +3 & 0 & 1.78 & 0.59 & + & + & \\
\hline 11 & - & - & 0 & 0 & 0.58 & 0.72 & + & - & abnormal \\
\hline 12 & - & - & 0 & 0 & 1.70 & 1.73 & + & - & \\
\hline
\end{tabular}

SS : single-stranded HBV DNA, SC : supercoiled HBV DNA, L: limear and full-lelength circular HBV DNA PDS : partially double - stranded HBV DNA. a + $1:<10 \mathrm{pg} / \mathrm{ml},+2: 10 \sim 100 \mathrm{pg} / \mathrm{ml},+3: 100 \sim 1000 \mathrm{pg} / \mathrm{ml}$.

$+4:>1000 \mathrm{pg} / \mathrm{ml}$, OD value at $492 \mathrm{~nm}$, negative $<0.5$. "ALT level for 12 mo to 16 mo follow - up period. N.D: not done.

肝内 HBV DNA と血中 HBV DNA との関係では 血中 HBV DNA が陰性化した 5 例のらち肝内 $\mathrm{HBV}$ DNA 2 例で消失し， 3 例で残存した。したがって IFN 治療によりまず血中 HBV DNA の消失がみられ た後に肝内 HBV DNA が消失した。

一方肝内 HBV DNA の動態は血中 HBe 抗原之密 接な相関があるとの報告がみられる21. 今回の成績で は HBe 抗原が消失した 5 例では肝内 HBV DNA は 消失もしくはSCの灭残存した。 Pre-S2抗原は肝内 HBV DNA が消失むしくはSCのみが残存した 3 例 で陰性化したが肝内 HBV DNA が消失しても Pre-S2 抗原は持続陽性の例すあり, $\mathrm{HBe}$ 抗原が肝内 $\mathrm{HBV}$ DNA とくKSS，L，PDS の各增殖形態の動態と密接 に関係していると考えられた。

次に IFN 治療後の肝炎の再燃についてはIFN 投与
終了後 1 年以上経過観察できた 6 例中 2 例で肝炎の再 然を認めたが，いずれるIFN 投与終了時に肝内 $\mathrm{HBV}$ DNA が陰性の例であった。このことは検出限界以下 の肝内 HBV が再び增殖し，肝炎の再燃をきたしたと 考えられた。一方武田はPre-S2抗原が陰性の場合はた と党 HBe 抗原が陽性であっても肝炎の再燃はみない と報告している3．今回の成績ですPre-S2 抗原が投 与後陰性化した例では肝次の再然をみなかった。した がって IFN 治療後の長期予後の予測には肝内 HBV DNA の消失のみではなく同時に Pre-S2抗原の持続的 な陰性化が必要である。

柬引用語：IFN 治療, 肝内 HBV DNA, Pre-S2抗原 女 献：1) Yokosuka O, et al：Hepatology $5: 728$ $-734,1985$ 2) Adrian O, et al : Gastroenterology $93 ： 1236-1241,1987$ 3) 武田 誠：肝霹 印刷中

\section{Effect of IFN treatment on HBV DNA in liver and changes of serum HBV assosiated markers - with a reference to reactivation of hepatitis-}

Masayuki Matsumoto*1, Tadao OKuno*2, Makoto TAKeda, Michiko ShIndo, Tatsuro Takino*1, Akira YAMADA, Jiro IMANISHI*3 and Yosihiro SouKaWA*4

\footnotetext{
*1 Third Department of Internal Medicine, Kyoto Prefectural University of Medicine (Kyoto)

*2 Department of Internal Medicine, Akashi Municipal Hospital (Akashi)

*3 Department of Microbiology, Kyoto Prefectural University of Medicine (Kyoto)

*4 Department of Biotechnology, Kyoto Institute of Technology (Kyoto)
} 